\title{
Skin Response Test Code
}

National Cancer Institute

\section{Source}

National Cancer Institute. Skin Response Test Code. NCI Thesaurus. Code C117674.

A character or string that represents the short code name of the skin response assessment. 